\title{
Translation and Culture: The Change of Cultural Atmosphere in the Translated Version of Ahmad Tohari's "The Red Bekisar"
}

Astari

Graduate Program

as.tari1392@yahoo.com

\begin{abstract}
This study is conducted in order to discover the difference between the original text, Bekisar Merah, and the translated text, the Red Bekisar. The analysis process and sample gathering will be using Peter Newmark's concept in translating and culture, while the analysis to reveal the use domestication in the translated text is supported by the definition stated by Hannun Kemppanen.

Keywords: translation, culture, domestication.
\end{abstract}

\section{Introduction}

Books are written to be read by massive amounts of people with messages inserted in them by the authors. In this matter, translating books into foreign language is a way to introduce them the world. Moreover, translating a creative work may require more effort and also prior knowledge related to the background culture of the creative work, rather than when translating academic articles or journals. There are numerous Indonesian books or novels which had been translated into English or vice versa. Although it is a way to introduce a creative work to a larger community, translating into a language different from the original language of the book is not a simple matter, especially when culture is involved.

Culture is inevitable as it is an inseparable part of every individual's life, therefore it will always be involved in anything people produce. Especially when the culture is of the author is strongly rooted in him or her. This will definitely be shown in the work as the culture of where someone was raised and nurtured influences him or her greatly. For instance, a person who was born in a traditional society of Javanese people would definitely live and behave the way a Javanese should. One of the example is how Javanese pay high respect to people who are older than them or a person whose position is higher. The way they speak to the elderlies or a person with high authority has to be polite and in a rather gentle manner. Through such way, one would be considered a proper Javanese.

Reading original version of the Red Bekisar written by Ahmad Tohari brings back the existence of a traditional Javanese society of Karangsoga in this modern day. Each of the description of the village vividly portrayed the ambience of a village located deep in the forest, far away from the main road. There are times, in several scenes in the book where it really feels as if those fictional characters are living in a whole different world. The way it is described about the trees in the forest, the numerous birds, chicken, and sounds of insects gives off the sensation of being in a village surrounded by a forest in Indonesia. Also, how Ahmad Tohari tells the readers that the people of Karangsoga are still wearing traditional clothing, such as kebaya and sarong, adds more of the Javaneseness to the novel. As for the English version, The Red Bekisar is translated by Nurhayat Indriyatno Mohamed who is currently the chief editor of Jakarta Globe.

According to Peter Newmark, translation is a craft consisting in the attempt to replace a written message and/or statement in one language by the same message and/or statement in another language" (Newmark 1981: 7). Therefore, I believe it does not only concern the literal translation, but also the culture embedded in the story. In addition, Newmark, regarding the definition of culture, said that he defines culture as the way of life and its manifestations that are peculiar to a community 
that uses a particular language as its means of expression (Newmark 1988: 94). His definition of culture sets a different perspective when I was reading both the original novel and the translated version. It becomes more obvious how culture is deeply rooted in the original text and Tohari's style or describing actions and settings help the readers to indulge themselves in the traditional ambience of Karangsoga or the authenticity of a Javanese society. On the other hand, it does not always feel as similar as the original text, for English is a more compact language compared to Bahasa Indonesia. Although, it cannot be denied that there are Javanese terms that are translatable and there are simply that are not. To try and find the correct translation for specific Javanese terms may end up changing the touch of it.

In the end, the difference in how each language is used becomes crucial in delivering the cultural aspects in the novel. If the translator is not able to translate or choose the right choice of words or his way of translating, the meaning, feel, and impression readers perceive might change. This novel by Ahmad Tohari is a rather delicate piece or work with its delicacy in using words and poetically tells the story in a way readers can still feel the Javanese atmosphere in the entire book. It would be a pity to not find such atmosphere in the translated version, because even the very traditional attitude and behavior of Lasi as a Javanese woman and wife would not be seen as vivid as it is in the original text. This also applies to other aspect of Javaneseness used in the story, such as pronouns and honorifics in Javanese, religious utterances, and some Javanese sayings or proverbs.

Newmark in Translation and Culture admits that it is not entirely possible to translate all of the aspects of culture in a language. If one should do such a translation, it would nearly be impossible as it will be harder than difficult to translate. He also stated that if a language is deeply involved in cultural features, such as plants or animals, it will cause problems in the translation process (Newmark 1988: 95).

Concerning terms and cultural aspects in a language, there is a set of Cultural Categories offered by Newmark. Through these some of these categories, I am going to compare the original text with the translated version, in order to reveal the differences of word choice could shift the meaning. The categorization will start from cultural aspects that are related to organizations, customs, activities, procedures, and concepts. This category would focus more to the religious aspect and customs of the people of Karangsoga. The last category is gestures and habits where I will be discussing about how Javanese people, especially Lasi, conduct themselves and compare them to the translated version (Newmark 1998: 95). Lastly, through the discussion using these cultural categories, I hope to find and see how different choice of words or terms could change the entire atmosphere of the book.

"The term domestication is used in translation studies for a strategy involving a translation practice where elements foreign to the target culture are replaced by more familiar ones."

(Kemppanen, H. 2012,

In addition, I am suspecting that there are some parts of the Red Bekisar which are domesticated to suit the culture of the target readers who are non-Indonesians. By using domestication as a strategy in translating this book, there are, indeed, Javanese terms and sayings which are too difficult to understand without having the background knowledge of the original author's cultural background. Therefore, those terms are found the Western terms which have similar meaning or convey the same idea as the original one. This does help non-Indonesian readers to grasp the messages the author would like to convey, although this strategy changes the Javanese impressions possessed by Bekisar Merah.

\section{The Translated Cultural Aspects}

In this section, I would like to discuss further about the cultural aspects in the original version which are translated into English. There are, apparently, changes in which give the English version a different atmosphere from the original version.

\section{Pronouns and Honorifics in Javanese}

Javanese people, especially the traditional ones, are known to be polite when it comes to addressing people who are either older or with authority higher than them. It will be considered as 
inappropriate if the young ones are to address elderlies and authorities without proper pronouns or honorifics. In this novel which is filled with the thick accent of Javanese society, the original text gives heaps of dialogues and paragraphs which includes the Javanese pronouns and honorifics.

Pronouns and honorifics used in Bekisar Merah are vividly showing how Javanese people are treating others regarding their positions in the society. If the person is an elderly, they usually use the pronoun Eyang which means Grandfather. Eyang itself does not only act as a pronoun, but also an honorific as to say or refer to a person who is an elderly and respected by the people in the society. There are several pronouns and honorifics used in Bekisar Merah, which are used accordingly and helps in identifying what sort of culture is embedded in the story.

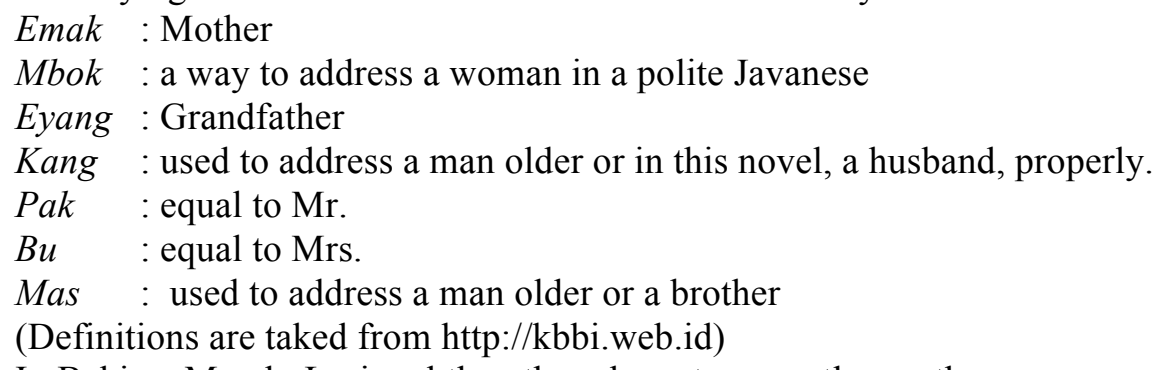

In Bekisar Merah, Lasi and the other characters mostly use those pronouns and honorifices when they address someone else. Moreover, those words are also used in the narrations to identify which character is which. By using these words, Tohari shows the Javaneseness of most of his characters though their words. This is quite different compared to Red Bekisar where some of those pronouns and honorifics are translated into English.

The translator's decision to translate those pronouns and honorifics, in some ways, changes the feel of the story. There is an example in the conversation between Lasi and Darsa in the first chapter, near at the very beginning of the story. They were talking about whether Darsa, the husband, should go and get the nira for that day or stay home and wait until tomorrow. They talked in a way the readers can see that they are actually a married couple, a Javanese married couple to be exact. This is seen from how Lasi address Darsa as Kang in Bekisar Merah, however, it did not happen in the Red Bekisar. In the Red Bekisar, there is no sign of Lasi using Kang to address Darsa as her husband, which is different from Bekisar Merah.

Original text:

"Las, apa aku harus tidak berangkat?"

"Kan masih hujan."

"Bagaimana bila aku berangkat juga?"

"Terserang, Kang. Tetapi kurang pantas, dalam cuaca seperti ini kamu bekerja juga."

"Masih, Kang. Uang juga masih ada sedikit. Kita besok masih bisa makan andaikata nira sore ini terpaksa tidak diolah."

"Tapi sayang sekali bila pongkor-pongkor dibiarkan tetap bergantungan dan niranya masam. Manggar bisa busuk."

"Ya. Soalnya, masih hujan lebat, Kang."

"Hujan masih lebat ya, Las?"

"Ya..."

(Tohari, A. 2013, 10-11)

Translated text:

"Las, do you think I should go out?"

"It's still raining."

"What if I go anyway?"

"That's up to you, but it doesn't feel right for you to work in this kind of weather." "Do we still have rice?"

"Yes, and I have a little money. We have enough to eat tomorrow even if we can't process today's nira."

"It seems such a shame to let the pongkors hang there waiting for the nira to curdle. It'll rot."

"But it's raining hard." 


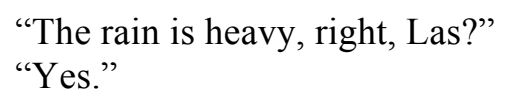

(Tohari, A., N. I. Mohamed, Trans. 2014, 4)

In this dialogue between Lasi and Darsa, in the English version shown in the quotation above, Lasi did not use the word or honorific Kang to address Darsa as her husband, whereas addressing a husband with Kang is what they consider as a proper way to call one's husband. By taking it away from some of Lasi's lines, her answers to Darsa becomes more straightforward and does not embody the gentle and polite Lasi as a conventional Javanese woman and wife at that era. A little part is omitted, but the change it gives is quite strong. Especially when I have read the original text, Bekisar Merah, and see how Lasi's politeness in talking to her husband can be indicated by her using Kang to address her respectful husband.

Besides the matter of Lasi's lines are not using Kang to call Darsa, there are honorifics that are translated and makes Red Bekisar appears to be more of a novel about a countryside in the West, rather than a small, remote village in Purwokerto. In the Red Bekisar, the word Emak is translated into Mother, which is similar to Eyang becomes Grandfather, the feeling of the story originates from Java is gradually fading. Those two terms are possible to keep as they are as the translator does not translate the term Mbok, as in Mbok Wiryaji, and Pak, as in Pak Tir. This inconsistency shows that it is actually possible to keep the Javanese pronouns and honorifics in the Red Bekisar to maintain the Javanese atmosphere of the story.

\section{Word choices in English vs. Javanese}

In translating, there are times when a translator is unable to find words which hold the exact meanings as the original ones. However, if the choice of words is not compatible with the original word, it would either change the meaning or change the feel about the words translated. In Bekisar Merah, there are words or terms in Javanese which are italicized and bold, which is probably done so because it is difficult to find words in Bahasa Indonesia which can par with the Javanese ones.

The first word which caught my attention in Bekisar Merah is, kaput (Tohari, A., 2013, 11). This Javanese word is used to describe Lasi's eyelids-less eyes and small that it is said to be almost none. In the Red Bekisar, kaput is translated into almond-shaped eyes, a term in which does not perfectly explain what kaput is in this matter.

Original text:

Orang sekampung mengatakan mata Lasi kaput.

(Tohari, A. 2013, 11)

Translated Text:

The people in the village said Lasi had almond-shaped eyes.

(Tohari, A., N. I. Mohamed. 2014, 4)

Another one is when the word is even omitted, such as the tem azimat and the utterance of oalah which is used when someone is surprised or when reacting to a certain situation. Also the word cabul is translated into submit, which does not explicitly describe what did happen to Lasi's mother when she was raped by a Japanese soldier. Therefore, even the changes of several Javanese terms, trivial or not, may change or gradually erase the Javaneseness in the book.

\section{Organizations, Customs, and Ideas: Religion and Norms}

Lasi lives in Karangsoga where Islam is a strong influence in the society, therefore, they are living with the values and norms combined from the traditions and religion. In Bekisar Merah, this religious atmosphere is supported by the religious terms and Javanese sayings or proverbs related to the God-human relationship. When a religious term is translated, into a more common or general language, the religiousness might disappear. An example is when Darsa fell of the coconut tree in the first chapter. In Bekisar Merah, Lasi uttered "Innalillahi..." which is a religious term in Islam, as in the Red Bekisar, it is translated into "Surely we belong to God". The translation itself is not wrong, however, to change a term that is supposed to be an exclamation said in a shock into an almost one sentence makes it a little strange. Moreover, it would not be strange to keep the term as Lasi and her society are obviously shown as a society with the majority of muslims.

$$
\begin{aligned}
& \text { Original text: } \\
& \text { "Innalillahi... ada - kodok - lompat?" } \\
& \text { (Tohari, A., 2013, 17) } \\
& \text { Translated text: }
\end{aligned}
$$


"Surely we belong to God. Is there a frog jumping?"

(Tohari, A., N. I. Mohamed, Trans. 2014, 9)

In Bekisar Merah, there are also some sayings or proverbs in Javanese related to the relationship between God and humans in Islam. Ahmad Tohari usually gives the proverbs or sayings in Javanese first, and then gives the meaning in Bahasa Indonesia. The Red Bekisar, on the other hand, does not always do the same as Bekisar Merah regarding this proverbs and sayings matters. There are ones that are directly translated into English and ones that are kept in Javanese. Also, there is one example which the translator changes the context of the Javanese sayings into a more general context.

Original text:

“....Kita sebaiknya nrima saja. Kata orang, nrima ngalah luhur wekasane, orang yang mengalah akan dihormati pada akhirnya."

Translated text:

(Tohari, A. 2013, 31)

"We'll turn the other cheek. It's said that those who turn the other cheek are respected in the end."

(Tohari, A., N. I. Mohamed. Trans. 2014, 20)

This saying is not simply translated, but also altered into another context which is probably done to suit the target readers' culture, Western culture. This decision has, once again, makes the ambience of Javanese society fades away, since the translation is taken from another religion. Moreover, the purpose of choosing that saying is not known to the readers, therefore, this saying is generally known by people.

Original text:

Yun ayun, ayun badan. Wong ayun susahing ati.

Badan siji digawa mati. Wong neng dunya sugih dosa.

Neng akherat dipun siksa. Gusti Allah, nyuwun ngapura.

Gendhung-gendhung pangeling-eling.

Padha elinga mumpung urip neng dunya.

Pada ngajia lawing tobat esih menga.

Gawe dalan maring suwarga.

Aja babad kudhi jungkir.

Babadana klawan puji lan dikir.

Menimbang diri dalam kesadaran hidup. Dan timbangan mengayun kesusahan.

Karena hidup akan beralih lewat pintu kematian.

Bila hidup di dunia banyak dosa, di akhirat bertemu siska.

Maka mintalah kasih sayang Tuhan.

Dan dengarlah tabuh pemberi peringatan.

Ingatlah selagi hidup di dunia.

Mencari ilmu, pintu pertobatan tetap terbuka.

Mari merintis jalan menuju kasih sayang Allah.

Bukan merintis dengan parang.

Melainkan dengan puji dan kecerdasannya.

(Tohari, A. 2013, 291)

Translated text:

If you weigh yourself in terms of life, the scale will tip forward hardship.

For life will pass through the gate of death.

If you live a sinful life, you will encounter suffering in the end.

Therefore, solicit Allah's mercy.

And listen to the drumbeat of the one who warns.

Remember it as long as you live in this world. 


\section{Seek knowledge, and the door to repentance will remain open. So let us clear the way to Allah's compassion. \\ Move forward not with a machete, \\ But praise and awareness.}

(Tohari, A., N. I. Mohamed. Trans. 2013, 219)

This chant in Javanese which is said by Eyang Mus in his surau is another example of how it is translated in the Red Bekisar. In Bekisar Merah, it is written in both Javanese and Bahasa Indonesia, which still gives off the original sense of this chant being a traditional way of Javanese muslim praising God. However, in the Red Bekisar, it is simply written in English without including the original text in Javanese. In the end, the translated version of this chant has the feeling more of a chant of a different religion if not for Allah is written there.

\section{Gestures and habits: The Javanese in the Attitude and behavior of Lasi}

Lasi is a classic Javanese woman. She is obedient and puts herself in a position where a wife should be. She often said that she is just a woman, therefore she will do as what people who hold authority on her said. Her being a Javanese woman and wife is seen, especially, through her dialogues. As mentioned in the first chapter, her dialogues with Darsa. Also there is another example of her sounds different from her original Javanese characteristics, where she sounds more of a modern and intelligent woman in the Red Bekisar.

Original text:

"Ya, Bu, kalau saya sudah dicerai, ya sudah. Saya kan cuma seorang perempuan."

(Tohari, A. 2013, 276)

Translated text:

"So be it. I'm only a woman."

(Tohari, A., N. I. Mohamed. Trans. 2013, 208)

This is a short dialogue between Lasi and $\mathrm{Bu}$ Lanting regarding her divorce with Handarbeni and the matter that Bambung wants to have her instead. In the original text, Lasi gives the impression of a woman, a wife, who is unable to do anything and decided to do what is told to ther. On the contrary, in the Red Bekisar, she sounds more cynical with such a short line to say, which does not resemble the image given in Bekisar Merah. Another time, Lasi, in a scene with Bambung talks about her pregnancy and how Bambung wants her to abort her baby. Lasi, in the end, strongly disagree with his idea.

Original text:

"Kalau dokter mau memeriksa untuk memastikan kehamilan saya, silakan saja. Saya malah sangat berterima kasih. Tetapi untuk menggugurkannya, saya tidak mau. Pak, tadi saya sudah bilang, saya hamil dan akan memelihara kandungan ini sebaik-baiknya. Tolong, Pak, pahami keinginan saya ini. Saya sudah lama, bertahun-tahun, ingin punya anak."

Translated text:

(Tohari, A. 2013, 330)

"If you want a doctor to confirm I'm pregnant, that's fine. I'd be very grateful, but I will never consent to an abortion. I'm pregnant and will look after my child as best as I can. This is what I want. I've waited many years for a child."

(Tohari, A., N. I. Mohamed. Trans. 2014, 248)

This dialogue too, has different impression from one another, between the original and the translated one. The original one, even when Lasi is being angry, she maintains her politeness through the use of Pak to address Bambung. In contrast to the original text, Lasi seems to be stronger and certain in conveying her thoughts and disagreement. She seems more forceful, compared to when she still calls Bambung using Pak. It is unfortunate to lose Lasi's Javaneseness in the Red Bekisar, because her way of talking to others using Javanese terms or honorifics shows more of the Javanese atmosphere. 


\section{Conclusion}

Translating a work with so much culture inside is proved to be a rather delicate and complicated process. Every choice of words ought to be considered carefully, because the closeness to the original language will help readers to experience the cultural aspects in the story or book. When a translator is not being careful in translating words in the source language, the meaning and impression might change. Such thing may confuse the readers, especially when the readers are able to speak or understand the language of the original text translated.

In the Red Bekisar, there are, often, times where the translator decided to omit some words or sentences, combine some sentences into one, or cut the sentence and change the orders of the sentences. These decisions, apparently, does not always result into a good translation. Reading both Bekisar Merah and the Red Bekisar had myself discovering how there are actually several translations in which does not really work when fully translated into English. There are times when it seems to be a better decision to keep a term or proverb as it is, in Javanese, and then the translator can translate it next to the original text or put the definition and explanation in the glossary at the end of the book.

After reading through the translation of Bekisar Merah, I found that there are times when domestication is used. The example is when the translator changes the saying about nrima, "nrima ngalah luhur wekasane, orang yang mengalah akan dihormati pada akhirnya", and in changed the entire saying into one which is more familiar to the target readers who are not Indonesians. "We'll turn the other cheek. It's said that those who turn the other cheek are respected in the end", this saying is often heard either in books, movies, or people saying it in public places. The meaning is more or less similar to the original text, and is domesticated for a reason. Although this does reduce, once again, the Javaneseness of Bekisar Merah.

In the end, it is inevitable that there are simply parts of the original text which are difficult or almost not possible to translate without domesticating them first. Although, domesticating the original text is not without consequences on its own.

\section{References}

Kemppanen, H. (2012). The Role of the Concepts Domestication and Foreignisation in Russian Translation Studies,. Domestication and Foreignization in Translation Studies, 4953. Retrieved June 06, 2016, from https://books.google.co.id/books?hl=en\&lr=\&id=OuTurITQfc4C\&oi=fnd\&pg=PA7 $\& \mathrm{dq}=$ domestication and foreignization in translation studies pdf\&ots=kwydxLUjk7\&sig=TBjlt4VUh16RIDDg8oyd1IH7QyI\&redir_esc=y\#v=on epage \&q\&f=false.

Newmark, P. 1981. Approaches to Translation. Oxford: Pregamon Press, 1981

Newmark, P. 1988. A Text Book of Translation. New York and London: Prentice Hall, 1988

Tohari, A. 2013. Bekisar Merah. Jakarta: Gramedia Pustaka Utama.

Tohari, A. (2014). The Red Bekisar (N. I. Mohamed, Ed.). San Marco, California: Dalang

Publishing. 